\title{
Effect of Inflation of India and United States on USD-Rupee Relationship
}

\author{
Ashutosh Bansal \\ Research Scholar, Bimtech (India)
}

\begin{abstract}
This paper aims to analyze the impact of Inflation on Currency exchange value against the changes in Inflation rate of the Domestic and Overseas Market major economies (i.e United States). Although all countries want stable and sustainable growth whereas Inflation rates (even of other countries) impacts economy at significant level. Through the 30 years Inflation data has shown that there is impact of United States \& India Inflation also on the INR value against USD.. This article aims to describe the stratergy adopted by policy makers to achieve sustainable growth $b$ monitoring the inflation .
\end{abstract}

Keywords: Inflation and Currency Values, US Inflation, Devaluing Indian Rupee

\section{Introduction}

Foreign Exchange Risk management is technique of minimising the risk due to fluctuation in value of currency in concern. If we talk of Indian Rupees against US Dollars. It could be easily observed that US dollar seems to be appreciated against the value of Indian Rupee with passage of time. Although it is tough to comment on any single reason for such sort of appreciation or depreciation of currencies. As there are so many factors at Micro and Macro level like Inflation, Interest Rates, Export-Import, Balance of Payment, Trade Deficit, Currency in Usage, Economic Policies of Nation or Union, Holding Tendency of Forex Traders/ Speculators, Circulation.

Although its tough to comment that what exact currency policy should be adopted so that economy would have sustainable growth. As strong local currency always indicates that there is productivity and sustainability in the economy of the country. But at same time it has to be evaluated that strong local currency might also attract the cheap imports and make it lucrative business and might not be good in the long term of the country's economy. This scenario has been observed with Singapore Dollars against USD. The basic distinction between Indian National Rupee and United States Dollar is that rupee acts as dependent variable whereas US Dollars are Independent Variable which impacts other aspects of currency value rather than Indian National Rupee which itself gets impacted.

As taking example it seems that US Forex market is more robust than Indian market. As there are number of factors a $\mathrm{n}$ recent talks and expectation of Britain exiting from EU losing one of its members, This Brexit cannot be taken as isolated as From India's point of view, World is Global village since past few decades, So Brexit is important because other then involvement in trade relations, EU is India's one of the largest distinct export market. With a population of approximately half a billion, the European economy is worth $\$ 16$ trillion, which is around one-fourth of global GDP. The good health of an economy is directly reflected by the state of its currency .Rupee may also depreciate because of the dual effect of Overseas fund outflow and dollar demand rise. It seems that it will also increase petrol and diesel prices to the level that government then may want to reduce additional excise duty levied on fuel when it was on a downward trend. This will increase fiscal deficit, unless revenue increased the Real Prices of gold, electronic goods, On the other hand cheaper rupee will make Indian exports, including IT and ITeS, competitive.

If UK exits the European Union which is expected from current scenario, the probability of investors moving more from emerging market currencies and euro/GBP investments, which in turn finally will lead investors to save their funds in safe haven of USD and US treasury, strengthens dollar against the other currencies.As EU is among the biggest trading partner to India, high depreciation in Rupee/Dollar could be expected. Even big giants Tata Motors-owned Jaguar Land Rover (JLR) has reportedly an estimated 1 billion pounds loss by 2020 after Britain's exit from the European Union.

\section{Theoretical Framework}

The theoretical literature provide substantiation regarding foreign exchange -Deepa Divakaran.N(2014) in "Currency depreciation causes and its impact Indian economy" Elucidate that Demand and supply theoFry is suitable if there is more requirement of dollars in the currency market and is not sufficiently matched by the supply, other things expected to be constant, the INR price of USD will go up or the rupee will depreciate.. Research paper also highlighted increased demand and prices for Petroleum / Crude Oil is also another reason for rupee fall. India has to import majority of its oil requirements to satisfy its domestic demand which is 
increasing significantly every year. The domestic demand for oil is increasing which finally results the price of the oil to increase in the global market. The requirement for dollar increases as we have to make payments in USD. It also engaged on the issue of Current Account Deficit which is due to high Imports against low Exports. Prof RavleenKaur, Robin Sirohi and the Research Paper -Effect of Ruppe Depreciation on Common Man- states that other then Current Account Deficit less Incoming FDI is also one of the reason The corruption scandals in the $2 \mathrm{G}$ and the coal-gate scam had derogated the India's image abroad.

ParidhiSaini ,ShivaliDhameja (2014) in "Rupee Dollar Value Trends Study of Influencing Factors" suggested by experts that the USD-Bombay Stock Exchange (Sensitivity Index) negative correlation may not always work. The negative relationship between the dollar index and the BSE- Sensitivity Index has become very unambiguous in the past few years. But this inverse correlation may not always be the same. A study by Guru (2009) indicated that the international markets (mainly OF United states) become active only after Indian markets closed and as a result there is an untold fear about the risks associated to overnight volatility in the currency pair. Once the domestic markets close, the positions cannot be sustained by the forex dealers till next day. The tax treatment of the profits or losses in the futures or forward currency market would this be considered as business income .

Shahid Ahmed Khan (2010) analysed that Interest rate is a very significant element in country's financial growth whereas exchange rate is a critical element of the international trade and important factor in country's sustainable financial growth. The USD currency exchange rate for different currencies showed variations for example -As USD was losing value against Euro and GBP but was increasing its value against Pakistani rupee. Pakistani rupee was reduced against dollar by $38 \%$ in just 2 months. At the same time, interest rate in U.S. reached to its lowest but in Pak it was decreased by $13 \%$ which is 260 times more than interest rate in United States (Nov. 09, 0.05\%). In the Globe, Pakistan has the highest rate of interest. This makes Banking in Pakistan a lucrative work. Pakistan despite of horrible law and order situation, worst political conditions, and lean economy.

Eduardo Borensztein( IMF ), analysed that Huge and sudden depreciations usually occur when an exchange rate peg is uncontrolled, often in the context of solid market burden or a balance of payments emergency. While in these situations there are always clear signs of overvaluation of the local currency, determining the magnitude of the essential nominal depreciation poses difficult questions. It could be considered that the depreciation should just compensate the estimated overvaluation, bringing the exchange rate back in line. However, some grade of pass-through to local prices is unavoidable, and thus it is necessary to overshoot the required depreciation initially.

Inflation rates in India had always shown rising trend adjoining the devaluation of the rupee and the erosion of the buying power of savings. Despite of Governmental interventions, the INR is in a free-fall, making it one of the most dreadful performing currencies globally. Reserve Bank made rate increases attempts to quiet the inflation in last few years but barely achieved any important result. Inflation rate continued increasing trend. This is now reflected through the currency devaluation. Inflation directly enhances prices and thereby affects the buying power of money. Currency price and inflation have a straight co- relation and impact each other. The currency reassessment is also important with the alteration in local prices affected by inflationary powers. Currency is considered to be hyped if the suitable alteration is not made with the price index variations. As world is becoming global village so taking finances and investing it somewhere is not very big deal for corporate. So they take cross currency and applies the concept of Absolute advantage and Relative advantage theory. It is the era where mobilising and exploiting resources word wide is not a tough job.

In this while taking inflation as one of the major parameter for deciding the Currency value there is Purchasing power parity (PPP) which states that exchange rate among currencies are in equilibrium when their buying power is the same in both the countries. It states that the exchange rate between two countries should equal the ratio of the two countries' price level of a predetermined basket of goods and services. When a nation's domestic price level is increasing ( country experiences price rises), that country's exchange rate must be reduced in order to go back to PPP.

The origin for PPP is the law of single price. In the absence of transportation and other operation costs, reasonable markets will equalize the price of an indistinguishable good in two countries when the prices are expressed in the same exchange. For example, a particular Laptop set that sells for 550 Singaporian Dollars [SAD] in Singapore should cost 300 US Dollars [USD] in Seattle when the forex between Singapore and the US is $1.833 \mathrm{CAD} / \mathrm{USD}$. If the price of the Laptop in Singapore was only $550 \mathrm{SAD}$, customer in Seattle would prefer buying the Laptop set in Singapore. If this procedure (called "arbitrage") is carried out at a outsized scale, the US consumers buying Singaporean goods will bid up the value of the Singaporean Dollar, thus making Singaporean goods more costly to them. This procedure continues until the goods have again reached to the equivalent price. There are three significant aspects with this law of one price. 1. transport costs, barriers to trade, 2. Significant markets for the goods and services in both nations 3. The law of one price only applies to marketable services \& goods; static goods such as houses, and many services that are local, are of course not traded connecting countries. 


\section{Objective}

The Objective of Research Paper is to analyse the relationship between Inflation of India and United States with change with value of Rupee against US Dollar. Although Inflation is not standalone factor to determine currency value but still important factor in determining currency value. As inflation impacts investment and Import, Exports also.

\section{Methodology}

To check the impact of Rupee value in context of US dollars, the data of 30 Years of Consumer Price Index of United States and India along with $1 \mathrm{USD}=\mathrm{X}$ Rupees value annual yhas been take and Multiple Correlation/ Regression analysis in SPSS has been applied.

\section{Hypothesis}

1. H0: Rupee Appreciation is not dependent on CPI of US.

H1: Rupee Appreciation has significant dependence on CPI of US.

2. H0: Rupee Appreciation is not dependent on CPI of India.

H1: Rupee Appreciation has significant dependence on CPI of India.

In the Table CPIus represents the Consumer Price Index of United Stated and CPI-india denotes the Consumer Price Index of India from period 1986-2015 and USD-INR is representing the value of 1 USD against rupees. This data is average of first date of every month of the said year. ( For i.e $1^{\text {st }}$ January $1985,1^{\text {st }}$ Feburary $1985 \ldots . .$. till $1^{\text {st }}$ December 1985 is an average of 1985 and so on, Source -www.moneycontrol.com).

\begin{tabular}{|c|c|c|c|}
\hline YEAR & CPI-US & CPI-India & USD-INR \\
\hline 1986 & $1.91 \%$ & $8.72 \%$ & 12.63 \\
\hline 1987 & $3.66 \%$ & $8.79 \%$ & 12.94 \\
\hline 1988 & $4.08 \%$ & $9.39 \%$ & 13.98 \\
\hline 1989 & $4.83 \%$ & $7.11 \%$ & 16.26 \\
\hline 1990 & $5.39 \%$ & $8.92 \%$ & 17.55 \\
\hline 1991 & $4.25 \%$ & $13.88 \%$ & 22.87 \\
\hline 1992 & $3.03 \%$ & $11.88 \%$ & 29.77 \\
\hline 1993 & $2.95 \%$ & $6.31 \%$ & 31.47 \\
\hline 1994 & $2.61 \%$ & $10.24 \%$ & 31.37 \\
\hline 1995 & $2.81 \%$ & $10.22 \%$ & 32.49 \\
\hline 1996 & $2.93 \%$ & $8.98 \%$ & 35.25 \\
\hline 1997 & $2.34 \%$ & $7.25 \%$ & 36.46 \\
\hline 1998 & $1.55 \%$ & $13.17 \%$ & 41.34 \\
\hline 1999 & $2.19 \%$ & $4.84 \%$ & 43.11 \\
\hline 2000 & $3.38 \%$ & $4.02 \%$ & 45.07 \\
\hline 2001 & $2.83 \%$ & $3.77 \%$ & 47.23 \\
\hline 2002 & $1.59 \%$ & $4.31 \%$ & 48.57 \\
\hline 2003 & $2.27 \%$ & $3.81 \%$ & 46.5 \\
\hline 2004 & $2.68 \%$ & $3.77 \%$ & 45.12 \\
\hline 2005 & $3.39 \%$ & $4.25 \%$ & 44.08 \\
\hline 2006 & $3.24 \%$ & $5.79 \%$ & 45.19 \\
\hline 2007 & $2.85 \%$ & $6.39 \%$ & 40.98 \\
\hline 2008 & $3.85 \%$ & $8.32 \%$ & 43.78 \\
\hline 2009 & $-0.34 \%$ & $10.83 \%$ & 48.26 \\
\hline 2010 & $1.64 \%$ & $12.11 \%$ & 45.58 \\
\hline 2011 & $3.16 \%$ & $8.87 \%$ & 46.87 \\
\hline 2012 & $2.07 \%$ & $9.30 \%$ & 53.705 \\
\hline 2013 & $1.47 \%$ & $10.92 \%$ & 58.25 \\
\hline 2014 & $1.62 \%$ & $6.37 \%$ & 61.14 \\
\hline 2015 & $0.12 \%$ & $5.88 \%$ & 64.23 \\
\hline
\end{tabular}

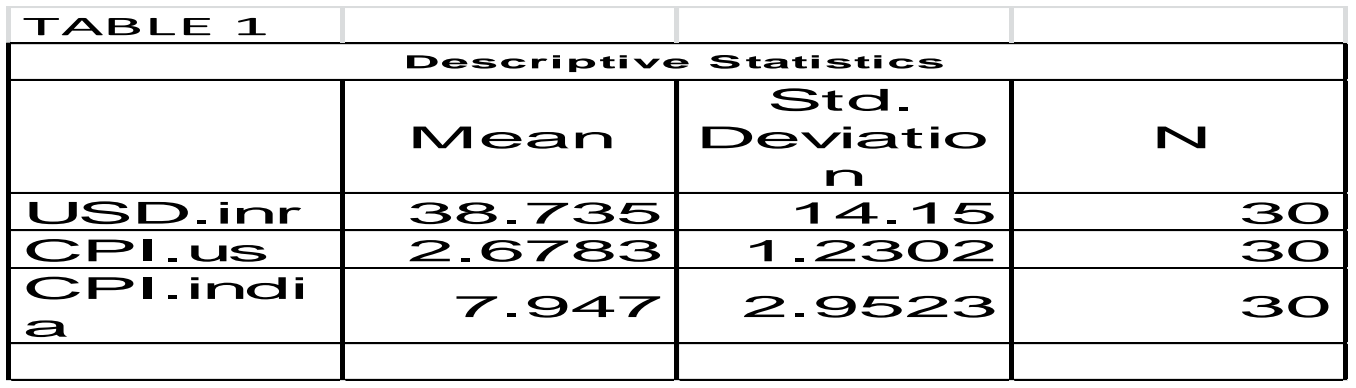


Table 2

\begin{tabular}{|l|l|r|r|r|}
\hline \multicolumn{5}{|c|}{ Correlations } \\
\hline & USD.inr & CPI.us & $\begin{array}{c}\text { CPI.indi } \\
\text { a }\end{array}$ \\
\hline & USD.inr & 1 & -0.652 & -0.303 \\
\cline { 2 - 5 } & CPI.us & -0.652 & 1 & -0.017 \\
\cline { 2 - 5 } & $\begin{array}{l}\text { CPI.indi } \\
\text { a }\end{array}$ & -0.303 & -0.017 & 1 \\
\hline
\end{tabular}

Table 3

\begin{tabular}{|r|r|r|r|l|}
\hline \multicolumn{6}{|l|}{ Model } & $R$ & $R$ Square & $\begin{array}{c}\text { Adjusted } \\
\text { R Square }\end{array}$ & $\begin{array}{c}\text { Std. Error } \\
\text { of the } \\
\text { Estimate }\end{array}$ \\
\hline 1 & $.652^{\mathrm{a}}$ & 0.426 & 0.405 & 10.91459 \\
\hline 2 & $.724^{\mathrm{b}}$ & 0.524 & 0.489 & 10.11613 \\
\hline \multicolumn{3}{|l|}{ a. Predictors: (Constant), CPI.us } \\
\hline \multicolumn{2}{|l}{ b. Predictors: (Constant), CPI.us, CPI.india } \\
\hline
\end{tabular}

\begin{tabular}{|r|l|r|r|r|r|r|r|}
\hline Table 4 & \multicolumn{7}{|c|}{ Coefficients(a) } \\
\hline & & Unstandardized Coeff & Standardized Coefficients \\
\hline Model & & B & Std. Error & Beta & t & Sig. \\
\hline & 1 & (Constant) & 70.962 & 6.815 & & 10.413 & 0 \\
\hline & CPI.us & -7.566 & 1.527 & -0.658 & -4.954 & 0 \\
\hline & CPI.india & -1.505 & 0.636 & -0.314 & -2.365 & 0.025 \\
\hline \multicolumn{7}{|c|}{ a. Dependent Variable: USD.inr } \\
\hline
\end{tabular}

It could be easily observed that since last 30 Years from ( 1986-2015) the average of Indian Rupee against USD is 38.738 and average Consumer Price Index is 2.67 in US and 7.94 in India it could be seen that even in average of these 30 years the CPI of India is 3 times the US CPI. But the result of correlation we could see that USD-INR prices are negatively correlated to CPI of India and US both. It means that increase in Inflation in US would decrease the value of Rupee against USD by -.652 as compared to the Indian CPI which is also negatively correlated but still not as negative compared to United States .Bit still Taking the inflation of both the places separately can't give us the right picture we have to represent it with the help of changes in Inflation of both years together.

In the above table it could be seen The "R" column shows the value of $R$, the multiple correlation coefficient. R can be considered to be one measure of the quality of the expectation of the dependent variable.

From the above table of model summary From the above table as value of $\mathrm{R}$ is 0.724 . A value of 0.724 , in this example, specifies a good level of extrapolation. R-Square column denotes the R2 value (also termed the coefficient for determination), which is the proportion of discrepancy in the dependent variable that can be explained by the self-determining variables. You can see from our value of 0.524 that our independent variables explain $52.4 \%$ of the variability of our dependent variable, USD-INR.

\section{Testing of hypothesis}

From Table Number 4- For Consumer Price Index- United States significance value is 0 which is less than the 0.05 level of significance which indicated the hypothesis-Ho is non acceptable ( rejected ) i.e. USDINR isnot dependent on CPI-US hypothesis (H1) is accepted .i.e Currency Exchange value has significant dependence on inflation of US. For Consumer Price Index -India value is 0 which is lesser than the 0.05 level of significance which means the hypothesis (H0) is rejected i.e. USD-INR is not dependent on CPI-India and alternate hypothesis (H1) is accepted .i.e. Currency Exchange value has significant dependence on inflation of India . 


\section{Suggestions}

Forex Rate is composite variable that depends on a number of macroeconomic variables like- Level of Forex Reserve-Low forex reserve is one more reason for currency fall. India's forex reserves have declined in recent past. Normally The main reason fo. So India has to import these at higher price. When the rupee value gets depreciated .-Dollar acquiring strength against other currencies- Dollar acquiring strength against other currencies is another reason as in today's world Cross Currency exchange rate also exists due to Arbitrage and ease in Global Financial Transactions. -Unclarity on Policy reforms- Non clarity on guidelines in reforms is another reason for reduction of currency. Then Key policies like Direct Tax Code and Goods and Service Tax have been in the discussion for years. -Interest rate difference-This is another factor, that is upper interest rate generally attract overseas investment but due to retard in growth there is rising pressure on RBI to reduce policy rates. In such circumstances investors stay away from domestic market. This effects capital account movements to India and put a decreasing pressure on rupee.

\section{Conclusion}

This research had to find out the relationship between Inflation (Consumer Price Index- India , United States) and significant economical factors and got some useful results linked to this. Multiple Correlation/ Regression study has been used to do the analysis based on annual basis. At last the result which came is that inflation of both India and United states significantly affects the value of Rupee against US Dollars.. The Inflation and Interest Rate difference makes the USD more lucrative for Speculators and Arbitrageurs. As they could take advantage of low inflation and low interest from the US market. This gap of Inflation and interest is so high that even buying USD at some premium is still profitable for Speculators and Arbitrageurs other then this Exim traders also takes benefit by Hedging and using same techniques to earn profit by $r$ these types of fall is due to heavy dollar sales by RBI to protect the rupee. -Demand and Supply-if there is extra demand of dollars in the currency market and is not effectively matched by the supply, other things remaining the same, the rupee value of dollar will go up or the rupee will decrease in value. Demand for dollars may be formed by importers requiring more dollars to give for their imports, foreign institutional investors thinning their investments, and taking USD outside nation. -Account Deficit- In BOP, Current account deficit occurs in a situation when country is importing more goods and services than that is exporting. -High demand for gold- higher demand for Gold or higher import of gold is considered as another reason for the financial crisis. In India there is a custom to put on gold and diamond stuff for the favourable occasions. So there is more needs for these but are not richly available in India creating more demand of USD which ultimately appreciates it.

It would not be wrong to say that Inflation is major reason for rupee always deprecating against US Dollars.

\section{References}

[1]. Bordo (eds.), A Retrospective on the Bretton Woods System: Lessons forInternational Monetary Reform, Chicago, Ill.: The University of Chicago Press.

[2]. Berg, A. and C. Pattillo (1998), “Are Currency Crises Predictable? A Test,” IMFWorking Paper WP/98/154.

[3]. Dornbusch, R. (1987), "Exchange Rates and Prices", American Economic Review, 77:

[4]. 93-106.

[5]. Dev, Mahendra and Sharma, Alakh (2010), 'Food Security in India: Performance,Challenges and Policies,' Oxfam Working Paper, Institute of Human Development, New Delhi.

[6]. Dholakia, Ravindra and Sapre, Amey (2011), 'Speed of Adjustment and Inflation-Unemployment Tradeoff in Developing Countries: Case of India,' Working Paper 2011-07-01, Indian Institute of Management, Ahmedabad.

[7]. Eichengreen, B. and C. Wyplosz (1993), “The Unstable EMS,” Brooking Papers ofEconomic Activity, vol. 24, No. 1, pp. 51-124.

[8]. Frankel, J. and A. Rose (1996), “Currency Crashes in Emerging Markets,” Journal ofInternational Economics, $41: 351$-366.

[9]. Goldfajn, I. and R. Valdés (1996), "The Aftermath of Appreciations”, NBER WorkingPaper No. 5650.

[10]. Iyer, Shriram (2008), The Rupee is Likely to Strengthen, The EconomicTimes,September 19.

[11]. Jaiswal, K. S. \&Saha, D. (2009), Currency Futures Trading in India, Indian Journal of Finance, Vol. 3(4), pp 28-34

[12]. Jaleel, K. Tania (2008), Emerging Markets Most Hurt in Bear Run, TheBusinesslineOctober 31.

[13]. Joshi, Rishsi (2008), "The Rupee Conundrum: Is India Inc. Prepared to Deal with theVolatility in the Indian Currency?", Business Today, Vol. 17, No. 21, October 19,pp 23-24.

[14]. Naik, G. \& Jain, S. K. (2002). Indian agricultural commodity futures market: A performance survey. Economic and Political Weekly.Vol. 37 (30).pp 3161-73

[15]. Patil, R. H. (2003).Exchange traded interest rate derivatives. Economic and Political Weekly.Money, Banking and Finance.Vol. 38 (8).pp 755-60 